
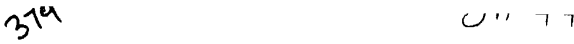

Agriculture, Ecosystems and Environment, 14 (1985) 95-102

95

Elsevier Science Publishers B.V., Amsterdam - Printed in The Netherlands

\title{
GRAM POD BORER (HELIOTHIS ARMIGERA) (HUB.) RESISTANCE IN CHICKPEAS ${ }^{1}$
}

\author{
S.S. LATEEF \\ Pulse Entomology, International Crops Research Institute for the Semi-Arid \\ Tropics, ICRISAT Patancheru P.O., A.P. 502324 (India)
}

(Accepted for publication 22 May 1986)

\begin{abstract}
Lateef, S.8., 1985. Gram pod borer (Hellothis armigera) (Hub.) resistance in chickpeas. Agric. Ecosystems Environ., 14: 95-102.

Heliothis armigere (Hub,) is the major pest of chickpeas (Cicer arietinum L.) through. out the Old World. Since 1976, using an open-field screening technique at ICRISAT Centre in India > 12000 germplaum accessions were screened, some of which were found to suffer considerably less pest damage than others. Subsequent tests confirmed a difference in susceptibility and found it to be the result of differences in oviposition and larval preference and retention on the plant. Cooperative studies with the MaxPlanck Institute for Biochemistry at Munich have shown that the amount of acid exudate on the leaves appears to be a useful criterion for diatinguinhing relatively resiatant, from susceptible, genotypes. ICRISAT plant breeders are presently attempting to intensify this resistance and to combine it with other useful factors, including resistance to fusarium wilt.
\end{abstract}

\section{INTRODUCTION}

Pulse crops (grain legumes) are the major source of protein for very many people in the developing nations, particularly where animal proteins are not commonly included in their diet. Whereas most of these crops are vulnerable to attack by several pests in the field and storage, chickpea (Cicer arietinum L.) has comparatively few insect pest problems.

Heliothis armigera (Hub.), $H$. virescens (FAB) and $H$. viriplaca (Hufnagel) are the most serious pests of chickpeas in most areas of the world, with $H$. armigera (Hub.) predominating on this crop throughout the Old World (Bhatnagar et al., 1982). The larvae feed voraciously on the crop from the seedling stage to maturity (Fig. 1). Surveys conducted by ICRISAT entomologists in India during the past 5 years have shown pod damage

\footnotetext{
' 8 ubmitted as J.A.No.448 by the International Crops Research Inotitute for the Semi-
} Arid Tropica (ICRISAT). 

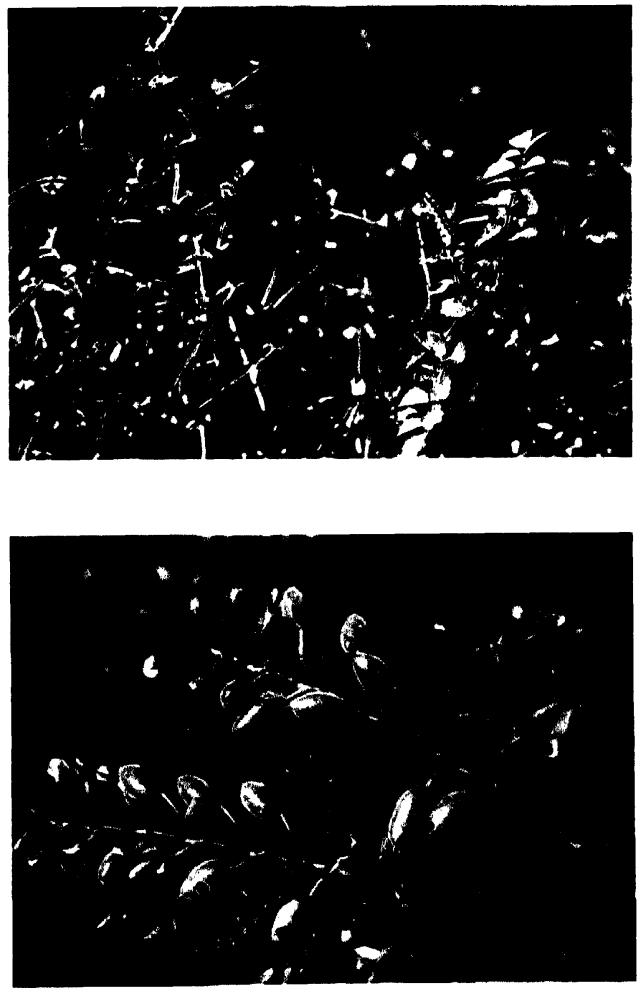

Fig. 1. Heliothis armigera damage to chickpea (Cicer arietinum L.) (top) plants; (bottom) pods. 
ranging from 0 to $84.4 \%$ in different states, with an overall average of $<8 \%$ (Sithanantham et al., 1984). Undoubtedly, $H$. armigera is the most damaging pest of chickpeas in most areas and years. Although this pest can easily be controlled with suitable insecticides, $<20 \%$ of the farmers use these (Reed et al., 1980). In view of the known variation in susceptibility to $H$. armigera among chickpea cultivars (Singh and Sharma, 1970) an intensive pest resistance screening programme was initiated in 1976 at the ICRISAT Centre (Davies and Lateef, 1978; Rogers, 1982; Reed et al., 1983).

Absolute resistance to Heliothis has been difficult to obtain in other crops such as groundnut (Campbell et al., 1982), so emphasis has been placed on selecting for reduced susceptibility and greater yields at maturity, compared to the local standard checks, for advancing the material.

\section{METHODS}

An open-field screening technique, using natural populations of $\mathrm{H}$. armigera, occasionally supplemented by laboratory-reared insects, was developed at ICRISAT Centre in India to identify sources of resistance to this polyphagous insect. The available germplasm of $>12,000$ accessions was screened on unreplicated single row $(1-\mathrm{m})$ plots. Many lines were rejected as being susceptible in these small-plot screening trials. The unreplicated tests were followed by a series of large plots $(2-5$ rows of $4 \mathrm{~m})$, replicated trials, each containing the more promising lines within a particular, narrow maturity range, with standard checks of the appropriate maturity. At every step all those entries that yielded less and also suffered greater pest damage than the checks were rejected.

In this way we have identified lines with considerable and consistently reduced susceptibility to $H$. armigera. The most promising of these have been identified to breeders, who have been attempting to intensify borer resistance and to incorporate Fusarium wilt resistance.

In order to study the mechanisms of $H$. armigera resistance, field and laboratory tests have been conducted to record oviposition on, and larval preference for, the different genotypes. In the field, resistant and suscep. tible cultivars representing different maturity groups were grown on two rows of $4 \mathrm{~m}$ in 3 replicates - RBD trials under unsprayed situations. Eggs and larvae of $\mathrm{H}$. armigera were recorded on 5 tagged plants at weekly intervals. For the laboratory tests a portion (ca. $15 \mathrm{~cm}$ ) of twigs bearing flowers and green pods were collected from these test entries and oviposition preference studies were carried out with the laboratory-bred moths. Collaborating with the Max-Planck Institute for Biochemistry, Munich, the chemical basis of pest resistance was initiated by analysing the plant exudates collected from the resistant and susceptible cultivars. 


\section{RESULTS AND DISCUSSION}

In the small-plot (one row of $1 \mathrm{~m}$ ) unreplicated tests, the major problem was that the uneven distribution of Heliothis infestation in space and time allowed some chance escapes from pest damage to be recorded as resistant. For example, in 1976-77, 8629 germplasm lines were tested in unreplicated plots, of which 955 had no $H$. armigera damage. However, a significantly higher proportion of borer damage-free samples were recorded from the plots of two check cultivars, which had been planted between every 20

\section{TABLE I}

Screening chickpea germplasm for susceptibility to $H$. armigera. Plots found to be free from damage in harvested samples, ICRISAT Centre during 1976-77

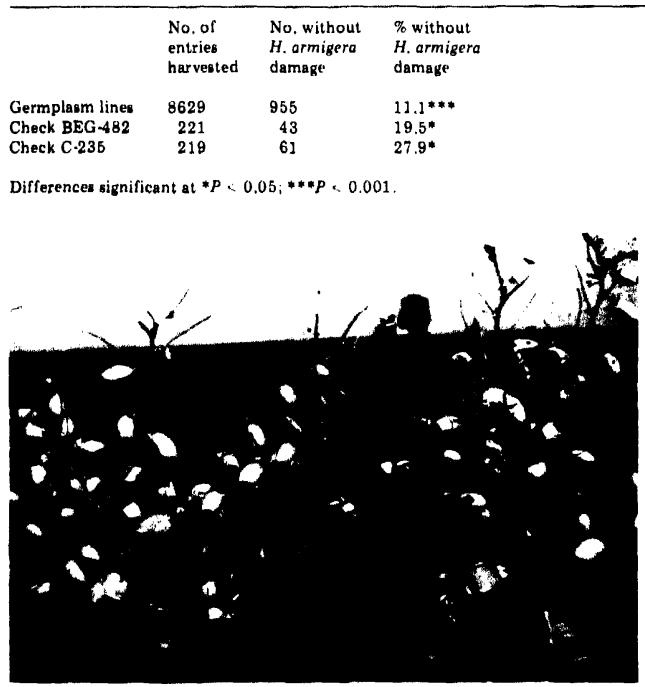

Fig. 2. A comparison of $H$. armigere resistant (cv. ICC-506) and sueceptible (cv. An. nigeri) plants. 
plots of germplasm (Table I). The genotypes that had little or no damage in these unreplicated tests were obviously escapes, some showed consistently reduced susceptibility when compared in the subsequent replicated trials.

The ability of some chickpea genotypes to compensate for early losses has also been found to be very marked, so that selections were made not only for resistance but also for tolerance or compensation, both of which would be expressed in the yields under pesticide-free conditions.

Resistant or tolerant lines of chickpea which gave a consistently good performance under unsprayed situations have now been identified (Fig. 2). The results from some of the most promising selections are shown in Table II.

\section{TABLE II}

Chickpea cultivars showing differences in their susceptibility to $H$. armigera at ICRISAT Centre, Patancheru, AP, India, in different trials and years

\begin{tabular}{|c|c|c|c|c|c|c|c|c|c|c|}
\hline \multirow[t]{2}{*}{ Cultivars } & \multicolumn{2}{|c|}{$1979 / 80$} & \multicolumn{2}{|c|}{$1980 / 81$} & \multicolumn{2}{|c|}{$1981 / 82$} & \multicolumn{2}{|c|}{$1982 / 83$} & \multicolumn{2}{|c|}{$1983 / 84$} \\
\hline & $\mathrm{PD} \%$ & $\mathrm{RR}$ & PD\% & $\mathrm{RR}$ & $\mathrm{PD} \%$ & $\mathrm{RR}$ & $\mathrm{PD} \%$ & $\mathrm{RR}$ & PD\% & RR \\
\hline \multicolumn{11}{|c|}{ Desi - eariy maturity group: } \\
\hline ICC.506 & 5.7 & 3 & 4.5 & 3 & 5,2 & 3 & 7.1 & 3 & 12.3 & 3 \\
\hline ICC 10619 & 5.0 & 3 & 5.2 & 3 & 7.5 & 3 & 21.0 & 4 & 11.1 & 4 \\
\hline ICC -6663 & 4.3 & 3 & 9.9 & 4 & 4.1 & 3 & 12.0 & 3 & 4.2 & 3 \\
\hline ICC 10667 & 5.6 & 3 & 5.9 & 3 & 8.1 & 4 & 14.2 & 3 & 2.6 & 2 \\
\hline ICC. 10817 & 5.6 & 3 & 8.3 & 3 & 7.3 & 3 & 16.4 & 4 & 18.9 & 4 \\
\hline $\begin{array}{l}\text { Annigeri (check) } \\
\text { IC- } 73266-34-1 \mathrm{P}\end{array}$ & 15.8 & 6 & 20.0 & 6 & 15.4 & 6 & 29.3 & 6 & 29.4 & 6 \\
\hline (susceptible) & 23.4 & 9 & 22.6 & 6 & 14.9 & 6 & 33.0 & 8 & 29.5 & 6 \\
\hline \multicolumn{11}{|c|}{ Desi - mid-and mid-late-maturity group: } \\
\hline IC. $738-8 \cdot 1-1 P \cdot B P$ & 5.7 & 3 & 7.3 & 3 & 4.9 & 3 & 23,4 & 5 & 11.4 & 3 \\
\hline $\begin{array}{l}\text { IC. } 7341 \cdot 12 \cdot 1 \cdot B \\
\text { IC. } 7394 \cdot 18 \cdot 2 \cdot 1 P \text {. }\end{array}$ & 11.3 & 5 & 13.0 & 4 & 7.6 & 4 & 21.1 & 4 & 3.8 & 3 \\
\hline $\begin{array}{l}\text { BP } \\
\text { IC. } 3137 \text { (6uscep. }\end{array}$ & 8.0 & 4 & 17.8 & 5 & 8.8 & 5 & 19.1 & 4 & 12.4 & 5 \\
\hline $\begin{array}{l}\text { tible) } \\
\text { IC.7320-11-1. }\end{array}$ & 13.6 & 9 & 40.7 & 8 & 33.6 & 9 & 48.6 & 9 & 25.3 & 9 \\
\hline $\mathrm{H} \cdot \mathrm{B}$ & 2.8 & 2 & 4.8 & 4 & 3.8 & 3 & 9.4 & 4 & 4.4 & 6 \\
\hline \multicolumn{11}{|c|}{ Kabuli - mid-late-maturity group: } \\
\hline IC -10870 & 7.4 & 3 & 17.0 & 6 & 11.0 & 3 & 13.8 & 5 & 4.4 & 4 \\
\hline $\begin{array}{l}\text { ICC- } 5264 \\
\text { ICC-8835 (sus. }\end{array}$ & 12.0 & 6 & 7.4 & 4 & 9.5 & 3 & 7.6 & 3 & 2,5 & 3 \\
\hline $\begin{array}{l}\text { ceptible) } \\
\text { L-550 (check) }\end{array}$ & $\begin{array}{l}14.9 \\
12.1\end{array}$ & $\begin{array}{l}6 \\
6\end{array}$ & $\begin{array}{l}21.2 \\
18.1\end{array}$ & $\begin{array}{l}7 \\
6\end{array}$ & $\begin{array}{l}\text { NR } \\
39.4\end{array}$ & 6 & $\begin{array}{l}19.1 \\
13.8\end{array}$ & $\begin{array}{l}6 \\
6\end{array}$ & $\begin{array}{l}26.7 \\
15.4\end{array}$ & $\begin{array}{l}9 \\
6\end{array}$ \\
\hline
\end{tabular}

PD\% = Percentage of pods damaged by $H$, armigera; $\mathrm{RR}=$ Relative reaistance rating 1-9:1 = resistant, 9 = susceptible (Lateef and Reed, 1983); NR = not recorded. 
TABLE III

Differences in oviposition by $H$, armigera moths and larval retention on some chick pea cultivars, shown as means of 3 replicates, in weekly counts during 1982-83

\begin{tabular}{|c|c|c|}
\hline \multirow[t]{2}{*}{ Cultivars } & \multicolumn{2}{|c|}{9 counts (weekly) } \\
\hline & $\begin{array}{l}\text { Eqgs } \\
\text { on } 5 \\
\text { plants }\end{array}$ & $\begin{array}{l}\text { Larvae } \\
\text { on } 5 \\
\text { plants }\end{array}$ \\
\hline Early flowering & & · \\
\hline ICC.506 & 38 & 58 \\
\hline Annigeri (check) & 64 & 103 \\
\hline \multicolumn{3}{|l|}{ Mid-flowering } \\
\hline ICC -10619 & 57 & 99 \\
\hline ICC-3137 (surceptible) & 77 & 202 \\
\hline \multicolumn{3}{|l|}{ Late flowering } \\
\hline $1 C C \cdot 7320 \cdot 11.1$ & 36 & 112 \\
\hline $\begin{array}{l}\text { ICC-5264-E9 } \\
\text { ICC. } 8835 \text { (borer }\end{array}$ & 53 & 132 \\
\hline susceptible) & 57 & 147 \\
\hline SE of mean $t$ & 12.7 & 15.3 \\
\hline
\end{tabular}

The susceptibility of the cultivar to attack by $H$. armigera was found to be the result of differences in oviposition (oviposition preference) and in larval preference and retention on plants. Some movement of 111 and IV instar larvae between plants and from plot to plot was observed, especially from the resistant to the susceptible plants, which was attributed to unfavourable or repellent characters of the resistant plants. The results of one such study on some of these selections are presented in Table III.

Some aspects of the various mechanisms of resistance in this crop were studied. The foliage, stems and pods of chickpea have a dense cover of glandular hairs which exude a very acidic liquid. This exudate, which has a $\mathrm{pH}$ of approximately 1.3 a high content of malic acid, was thought to be a major factor limiting the range of pests which attack this crop. With the help and cooperation of the Max.Planck Institute for Biochemistry at Munich, the composition of the exudate collected from chickpea cul. tivars having different susceptibilities was analysed. It was found that differences between cultivars in the level of malic acid, a major component of this exudate, could be used as an index of susceptibility of a cultivar to attack by $H$. armigera. A higher level of malic acid was detected from resistant cultivars compared to the susceptible ones (Rembold, 1981; Rembold and Winter, 1982). 
Most of the lines having resistance to Heliothis are highly susceptible to wilt caused by Fusarium oxysporum f. sp, ciceri. This wilt is widespread in chickpea-growing areas but particularly common in central and peninsular India, where Heliothis causes most damage. A programme to breed for lines having a combined resistance to both Heliothis with Fusarium wilt has been initiated. This would provide an extremely useful cultivar for subsistance farmers in the semi-arid tropics, who are unable to afford chemical control measures.

\section{CONCLUSION}

In the semi-arid tropics the most appropriate means of reducing the losses caused by Heliothis armigera in chickpea was to breed for some form of resistance, tolerance or compensatory ability. Accordingly, material from extensive germplasm collections, breeders' crosses and disease resistant materials were screened in the open field trials for resistance or tolerance to this pest. The results have been encouraging and cultivars have been selected which either suffer much less damage, or whose ability to compensate for losses and recovery is rapid enough to produce worthwhile crops in the presence of this pest. A high malic acid content of leaf exudates was found to be associated with resistance to $H$. armigera.

\section{ACKNOWLEDGEMINT}

The author is grateful to V.R. Bhagwat, Research Associate, ICRISAT, for his help in carrying out these studies and to Dr. W. Reed, Principal Entomologist (Pulses), ICRISAT, for his guidance and useful suggestions.

\section{REFERENCES}

Bhatnagar, V.S., Lateef, S.S., Sithanantham, S., Pawar, C.S. and Reed, W., 1982. Research on Heliothis at ICRISAT. In: Proceedings of the International Workshop on Heliothis Management, 15-20 Nov 1981, at ICRISAT, Patancheru, AP, India, pp. 385-396.

Campbell, M.V., Wynne, J.C. and Stalker, H.T., 1982. Screening groundnut for Heliothis resistance, In: Proceedings of the International Workshop on Heliothis Management, 15-20 Nov 1982, at ICRISAT Centre, Patancheru, AP, India, pp. 267-276.

Davies, J.C. and Lateef, S.S., 1978. Recent trends in grain legumes pest research in India. In: Singh, S.R., van Emden H.F. and Taylor, T.A. (Editors), Pests of Grain Legumes: Ecology and Control, IITA/Academic Press, London, pp. 25-31.

Lateef, S.S. and Reed, W., 1983. Grading plant genotypes for their resistance to insect pests in a field screening programme. Paper presented at the national seminar on breeding crop plants for resistance to pests and diseases, TNAU, Coimbatore, 25-27 May, 1983 (Proceedings in press). 
Reed, W., Latoef, 8.8. and Bithanantham, 8., 1980. Ineect peet management on chickpea. In: Proceedinge of the International Workehop on Chickpes Improvement, $28 \mathrm{Feb}-2$ Mar, 1979, Hyderabed, AP, India, pp. 179-188.

Reed, W., Reddy, K.V.B., Lateef, 8.8., Amin, P.W. and Davies, J.C., 1983. Contribution of ICRIBAT to studies on plant resintance to insect attack. In: Whitehead, D.L. and Bowers, W.S. (Editore), Natural Producte for Innovative Peat Management., Pergamon Press, Oxford, pp. $480-449$.

Rombold, H., 1981. Malic acid in chickpen exudate a marker for Heliothis reaistance. International Chickpes Newdetter, ICRISAT, No. 4: 18-18.

Rembold, H. and Winter, E., 1982. The chemiat's role in host plant resistance atudies. In: Proceedinge of Intornational Workahop on Heliothis Management, 15-20 Nov. 1981, at ICRISAT Centre, Patancheru, AP, Indie, Pp. 241-250.

Rogers, D.J., 1982. Screening legumes for resistance to Heliothis. In: Proceedings of the International Workahop on Hellothis Management, 15-20 Nov. 1981, at ICRISAT Centre, Patancheru, AP, India, pp. 277-287.

Singh, H. and Bherma, 8.8., 1870. Relative auceptibility of come important varieties of gram to Heliothis armigera Hubner. Indian J. Entomol., 32: 170-171.

Bithanantham, 8., Reo, V.R., and Ghaffar, M.A., 1984. International reviow of crop lowes caused by inects on chickpea. In: Proceeding of the National Seminar on Crop Lowes due to Ineect Peats, $7 \rightarrow$ Jan 1983, at APAU, Hyderabad, India, pp. 268-283. 